\title{
Grice's Cooperative Maxims as Linguistic Criteria for News Selectivity
}

\author{
Reza Kheirabadi \\ Department of Linguistics, Tarbiat Modares University, Tehran, Iran \\ Email: rkheirabadi@gmail.com \\ Ferdows Aghagolzadeh \\ Department of linguistics, Tarbiat Modares University, Tehran, Iran \\ Email: aghagolz@modares.ac.ir
}

\begin{abstract}
The language of the news has been in the center of attention of both media researchers and linguists for decades and the criteria by which the news editors and journalists decide about newsworthiness of an event or story, widely known as news values, have been one interesting aspect of news production process especially for critical discourse analysts. In this paper, we review the wide range of news values lists proposed by media scholars and linguists since the publication of Galtung and Rouge's leading article (1965) and suggest Grice's cooperative maxims as linguistic set of news values. The purpose of this study is to show that news can be considered as a mutual conversational activity between the media and its audiences, as a result the maxims ruling the conversation process are respected in news production process too. In other words, in this article we show that an indispensible number of criteria or news values, pinned down by media researchers in recent decades are actually rewording of these maxims and journalists are actually aware of these pragmatic maxims while composing their news stories. we can trace the related evidence of respecting these four maxims(Quality, Quantity, Manner and Relevance) in the news in the way they are observable as hedges in conversational activities, showing that they have in- action linguistic equivalences . However, as Grice himself noticed, the maxims may be violated (flouted) in different situations and maxim flouting leads to implicature.
\end{abstract}

Index Terms - language of the news, news values, Cooperative Principle, Paul Herbert Grice

\section{INTRODUCTION}

Every day many different events happen all around the world but very few number of them, after passing through a so called "gate keeping" process are published and broadcasted as news.

"Since1950s, both scholars and practitioners examining the gatekeeper function of the news media have sought to explain why some issues and events become newsworthy while others remain obscure." (Albert Braun, 2009, p.1)

According to some media researchers, they refer to a set of so-called "News Values" which enables them to make decision whether a news story has enough technical and professional potentiality (values) to be reported in competing with other potential possibilities.

The study of news values has been considered as an important field of exploration within journalism researches because it is a way of making more transparent a set of practices and judgments which are otherwise shrouded in opacity, as Stuart Hall (1973, p.181cited in O'Neill and Harcup , 2009, p.163 ) argues:

"News values" are one of the most opaque structures of meaning in modern society [...] Journalists speak of "the news" as if events select themselves. Further, they speak as if which is the "most significant" news story, and which "news angles" are most salient are divinely inspired. Yet of the millions of events which occur daily in the world, only a tiny proportion ever become visible as "potential news stories" and of this proportion, only a small fraction are actually produced as the day's news in the news media. We appear to be dealing, then, with a "deep structure" whose function as a selective device is un-transparent even to those who professionally most know how to operate it."

The starting point of news values analysis goes back to 1965 when Galtung and Rouge published their widely known and referred to article in which they studied the coverage of three major international crises (Congo, Cyprus and Cuba) in four Norwegian newspapers and proposed some alternative approaches to reporting the foreign news in the press. Galtung and Ruge in their attempt to answer the question of "How do events become news?" presented the following list of newsworthiness elements consisting of 12 factors also known as Galtung and Ruge's news values list:

1- Frequency: An event that unfolds within a publication cycle of the news medium is more likely to be selected than a one that takes place over a long period of time.

2- Threshold: Events have to pass a threshold before being recorded at all; the greater the intensity (the more gruesome the murder or the more casualties in an accident), the greater the impact and the more likely it is to be selected. 
3- Unambiguity: The more clearly an event can be understood and interpreted without multiple meanings, the more likely it is to be selected.

4- Meaningfulness: The culturally familiar is more likely to be selected.

5- Consonance: The news selector may be able to predict (due to experience) events that will be newsworthy, thus forming a "pre-image" of an event, which in turn increases its chances of becoming news.

6- Unexpectedness: Among events meaningful and/or consonant, the unexpected or rare event is more likely to be selected.

7- Continuity: An event already in the news has a good chance of remaining in the news (even if its impact has been reduced) because it has become familiar and easier to interpret.

8- Composition: An event may be included as news less because of its intrinsic news value than because it fits into the overall composition or balance of a newspaper or news broadcast.

9- Reference to elite nations: The actions of elite nations are seen as more consequential than the actions of other nations.

10-Reference to elite people: Again, the actions of elite people, likely to be famous, may be seen by news selectors as having more consequence than others, and news audiences may identify with them.

11- Reference to persons: News that can be presented in terms of individual people rather than abstractions is likely to be selected.

12- Reference to something negative: Bad events are generally unambiguous and newsworthy. (Galtung and Rouge 1965 cited in O’Neill and Harcup , 2009, p.164-165)

Since the publication of this seminal article, many linguists and media researchers have been studying about and criticizing on the notion of news value(s) and some various lists of so called news factors have been proposed by them. O'Nail and Harcup (2009) mention and review only some of the most probably well known ones such as Golding and Elliott (1979), Gans (1980), Bell (1991), Allern (2002) and finally they open the discussion to further exploration and write: "All such taxonomies of news values must "remain open to inquiry rather than be seen as a closed set of values for journalism in all times and places" (Zelizer, 2004, p. 55); and further research is needed to measure the extent to which the above news values apply to other forms of media, in different societies, and how they may change over time." (ibid, p.168)

As mentioned in citation above, many attempts were done to identify news values in different means of communication (News values in Radio, Television and Internet websites), different societies (Asian news values for examples!) and various cultural, social, economic and experimental backgrounds. The most recent development in the news production analysis is the ethnographic approach in which researchers with training in linguistics go into the newsrooms and observe the daily routines of making news.(See especial edition of journal of pragmatics, vol.43, Issue 7(May 2011) for discursive perspectives on news production.)

The study of news values was not limited to the Western researchers only, Aghagolzade and Kheirabadi (2008) is one of the researches done in a non-western press atmosphere in which the authors studied a corpus of hard news published in four Iran newspapers to testify the conclusions and see which factors mentioned by Galtung and Ruge are playing the major role in news selection process.

They conclude their paper as: "In this research, 303 headlines were chosen from the front pages of four Iranian newspapers in which 426 news values distinguished, considered and analysed. This study showed that in Iranian newspapers, "Reference to elite people" and "Consonance" play the main role as news values. (Aghagolzade and Kheirabadi, 2008, p.7)

They also pay attention to the role of Ideology or specific group attitude, social identity and the interest of social groups, religious belief, patriotism and sentiment in selection process of Iranian newspapers.

As time went by, more recent approaches to news and media study emerged and the result (besides the seemingly endless new lists of news values) was the ethnographical and in-action approach to study the news production process and linguists, especially (Critical) Discourse Analysts, have shown a powerful interest to news analysis from different perspectives and within different theoretical frameworks a. For them, news as a type of discourse has been considered as a very interesting topic of linguistic analysis and pioneering works such as van Dijk (1988), Fairclough (1989), Fowler (1991) and Bell(1991), are few examples of linguistic studies which have been done in field of news and media analysis both in theory and practice.

In this paper we focus on the idea of suggesting a linguistic set of news values and our purpose is to show that Paul Grice's Cooperative Principle maxims (Quality, Quantity, Manner and Relevance) can be introduced as the linguistic criteria or values of news production. In other words many of the so-called items, mentioned in various news values lists so far can be regarded as rewording of these four maxims. One of the benefits is showing the competency of Cooperative Principle (CP) in written texts such as news and shortening the long confusing endless lists of news values to a solid pragmatic set of linguistic criteria. In the following, first we go through some of the most well known lists of news values proposed by media researchers since 1965 and then try to summarize a considerable number of them under the CP maxims.

\section{News Values in Post-Galtung ERA}


As we mentioned above, after Galtung and Ruge's leading article was published in 1965, other media academics have revisited, Criticized and upgraded their conclusions. It is beyond the scope of this article to name all news values lists but in the following we mention only some of the most well-known lists of news values presented by different scholars in recent decades just to present a snapshot of how vast the subject of study in this field is:

In their research which was a critical study of Galtung and Rouge paper, Golding and Elliott (1979) considered "entertainment, drama, visual attractiveness, importance, size, negativity brevity, recency, personalities and elites" as the selection criteria in news production process.

Denis MacShane(1979, p. 46) subdivided newsworthy events into the following categories:

Conflict, Hardship and danger to the community, Unusualness, Scandal and Individualism.

Harcup and O'Neill's (2001 cited in Brighton and Foy,2007) study of the printed press resulted in their attempt to revise and update Galtung and Ruge's list as the following:

"Power élite, Celebrity, Entertainment, Surprise, Bad news, Good news, Magnitude, Relevance, Follow-ups And Media agenda."

Harrison (2006, p. 137) also lists a number of criteria by which news stories can be judged and listed:

"Availability of pictures or film (for TV), Short, dramatic occurrences, Novelty, Grand scale, Negative (violence, crime, confrontation, catastrophe), Unexpected Or expected, Relevance/meaning, Similar events already in the news Balanced programme, Élite people/nations, and Personal or human interest framing."

Allern (2002 cited in O'Nile and Harcup, 2009, p.167) put the role of economy into the center of his attention and suggested the following selection principles:

-The more resources it costs to follow up a story or expose an event/issue, the less likely it will become a news story.

- The more journalistically a potential news item is prepared/formatted by the source or sender, the greater the likelihood that it will become news.

- The more selectively a story is distributed to news organizations, the more likely it will become news.

-The more a news medium's strategy is based on sensationalist reporting in order to attract public attention and the greater the opportunity for accentuating these elements in a potential story, the more likely a story is to be used.

The number of news values and selection criteria has been always increasing during recent years like a leafing tree growing both from bottom and top! Although these seemingly endless lists have also encountered many strong and/or devastating criticisms mostly by those people who actually used to work as journalists (see O'Nile and Harcup (2009) and Brighton and Foy(2007) for some examples of these criticisms), the concept of news values as the criteria of deciding on newsworthiness is still widely studied, discussed and referred to. In the following section we will show how Grice maxims can be extended to the news texts and many of the news values especially in composition level (the level during which the news is written and then passes through gate keeping process) can be summarized under the terms of these maxims. However, we should keep in mind that the news production is a multilevel process and those criteria related to other stages such as publication level are not necessarily a part of this new inventory set of linguistic news values. In other words we try to show that news as a text is a mutual interaction between media and audiences, as a result Grice maxims are indispensible characteristics of news and can be introduced as a set of criteria covering a wide range of values suggested so far.

\section{LINGUISTICS APPROACH TO NEWS VALUES}

Language, as the major material of producing the news is the main subject of study in linguistics; as a result it is not strange to see many linguists working on the mutual interaction of media and language. Linguists such as Noam Chomsky (1988), Roger Fowler (1991), van Dijk (1998), Norman Fairclough (1992,1995,2003) Guy Cook (1992), and Michael Hoey(2001) have been working on this subject but publication of "News as Discourse" (1988) by van Dijk is regarded as the starting point of discoursive studies of the news. He categorizes the news values into various groups: "In general, different types of news values may be distinguished. First, are those news values formulated in the economic terms of news production in different market systems and within profit-oriented organizations."

... The second category of news values is more closely tied to the social routines of newsgathering and organizational production, which in turn are partly linked with the economic constraints (such as those of competition, leading to the professional aim to bring news as quickly and as reliably as possible, or to beat other media with a scoop).(van Dijk, 1988, p.120-121)

Here in the following we are to introduce a new set of news values which originally rooted in linguistics and definitely pragmatic concepts. In fact we aim to suggest that the very long list of news values can be reordered by considering four essential elements of communication as news values in composition level:

Grice (1989) proposed a principle with four maxims to formulate the ordinary human communication mostly known as Cooperative Principle (CP) which is summarized by him as: "Make your conversational contribution such as is required, at the stage at which it occurs, by the accepted purpose or direction of the talk exchange in which you are engaged." (Grice, 1989, p. 26).

He also defines the four maxims of $\mathrm{CP}$ as bellow:

1. Quantity (give as much information as is required, and no more than is required)

2. Quality (do not say what is false or that for which you lack adequate evidence) 
3. Relation (be relevant)

4. Manner (be clear, be orderly, and avoid ambiguity) (Ibid, p. 28).

In this paper we suggest the idea of expanding this principle and its maxims to the news discourse and show that a considerable set of news values are essentially rewording and paraphrasing these maxims. It is good to mention that the influence of Grice's ideas and especially CP on many scholars and scientific fields is not limited to this paper (See Lindblom in Mey,2009 for further discussion.)

\section{Linguistic Set of News Values}

The aim of this research is to introduce Grice cooperative principle and its relevant maxims as the linguistic criteria of news composition which is and should be regarded by journalists and news editors while making decision on newsworthiness on composition level. As we reviewed up to this part of article, there are various lists of news values proposed from 1960s on and we named only some of them in brief. In this stage we widely referred to Albert Braun(2009) who summarized various news values lists in his thesis; however, we refer to other lists whenever necessary. After categorizing the news values by their common features, we try to show that a considerable number of the elements (those criteria related to the composition of the news) are basically the same as Grice's CP maxims and then we will present some evidence from newspapers to prove this hypothesis in action. Let us focus on each Maxim and some relative news values to show the main idea of this research more in detail:

\section{Maxim of Quality:}

In some news values lists, we encounter the notion of numbers and statistics as the element which makes the news valuable to be reported. Here are some examples: Facility (Bell, 1991; Gregory \& Miller, 1998); Numbers (Hetherington, 1985); Voters, Survey Respondent, and other agreements (Gans, 1979) but the question is why referring to numbers and surveys can do it? Our answer is that because a number survey is a proof to observing the quality maxim and it tries to convince audiences about the truth of the news.

When journalists refer to numbers, statistics and facts and figures, they are indirectly trying to show the audience that their news is respecting the maxim of quality.

\section{Maxim of quantity:}

This maxim is also observable in the following news values:

Brevity (Bell,1991) ;Follow-Up (Harcup \& O'Neill, 2001);CO-Option (Bell, 1991; Gregory \& Miller, 1998), Meaningless (Galtung \& Ruge, 1965) Impact and Consequences (Herbert, 2000); Significance (Hetherington, 1985); Magnitude (Harcup \& O’Neill, 2001); Thershold (Galtung \& Ruge, 1965)

A news should be informative enough not too long and not too short and it is an accepted rule in news rooms that too long stories are edited because they are considered as boring and too short stories should be completed as soon as possible because they may seem meaningless to the audiences.

\section{Maxim of relation:}

This maxim may seem clear in the first look but as Grice himself mentioned it is very difficult to define it exactly: "Though the maxim itself is terse, its formulation conceals a number of problems that exercise me a good deal: questions about what different kinds and focuses of relevance there may be, how these shift in the course of a talk exchange, how to allow for the fact that subjects of conversations are legitimately changed, and so on. I find the treatment of such questions exceedingly difficult, and I hope to revert to them in later work." (Grice 1989, p.27)

A relevant news is a news which is relevant to the needs and interests of its audiences and the prestige of the media at the same time. This maxim is indirectly mentioned under other names and titles in various news values lists:

Relevance (O’Sullivan et al., 1983; Bell, 1991; Gregory \& Miller, 1998;McQuail, 2000; Harcup \& O’Neill, 2001)

Composition (Galtung \& Ruge, 1965); Political Balance (Warner, 1970), Cultural Response (Ryan, 1991); National Ceremonies (Gans, 1979); Consensus(O’Sullivan et al., 1983) Predictability And Routine (McQuail, 2000) Elite People (Galtung \& Ruge, 1965);, 1979); Elitism (Gregory \& Miller, 1998); Proximity(Ruehlmann, 1979; Hetherington, 1985; Ryan, 1991; MacDougall in Palmer, 1998; Herbert, 2000); Closeness (O'Sullivan et al., 1983; McQuail,2000); Domestic Affairs (O'Sullivan et al., 1983); Location Of Events (McQuail, 2000); Proximity To The Audience Of People And Events In The News (McQuail,2000).

As we see, the factor of relevance and to speak and write relatively is mentioned in many lists of news values under various titles even the relevance itself. In other words, the more relevant the news is to the needs of audiences, the more probable the selection is.

\section{Maxim of manner:}

The followings are only some of the news criteria in which the content of the manner maxim is in the center of attention: Unambiguity (Galtung \& Ruge, 1965) and Clarity (Bell, 1991 and McQuail, 2000).

A news should be unambiguous in composition level because it is not generally a highly scientific and academic writing which needs much background information to be understood.

As it is clear, journalists are aware of the importance of these maxims and while writing the news yhey try to observe them as much as possible. These criteria are also reflected in the news values lists suggested by different media researchers and it can be inferred that these maxims are checked by the editors as a set of newsworthiness criteria 
during the so called gate keeping process. In the following section, some evidences chosen from daily newspapers and news agencies reflecting the maxims are presented.

\section{SOME EvidENCE OF Grice MaXims In THE News}

There are certain kinds of expressions speakers use to mark that they may be in danger of not fully adhering to the principles, these kinds of expressions are called "hedges". (Yule, 2000, p.38) for example we may say: "I am not sure if this is right..." or "As far as I know..." to show that we respect the maxim of quality and many of us may use this cliché expression" So, to cut a long story short,..." to emphasize that we observe the quality maxim in communication process. We can observe many of such phrases and sentences in news stories also:

To sum up the story...

There are no more details about this news...(Quantity maxim)

The official sources announced that...

No one takes the responsibility of this report ...

It is heard that...(Quality maxim)

On this subject, we interview...(Relation maxim)

To clarify the news I talk to...(manner maxim)

In the following we mention some of such evidence chosen from articles and news published in international newspapers and news agencies :

1)... Field Marshal Hussein Tantawi, in comments carried by the nation's official news agency, also urged voters to turn out for the parliamentary elections starting on Monday...(maxim of quality is reinforced by mentioning the exact source of the news.)

(source:http://hosted.ap.org/dynamic/stories/M/ML_EGYPT?SITE=FLDAY\&SECTION=HOME\&TEMPLATE $=D E$ FAULT)

2)...The White House spokesman, Jay Carney, refused to provide further details. Asked whether the team that killed Osama bin Laden had come under fire, Carney said the White House had gone to the limit in providing details and that any more would risk future operations. "I am not going to get into operational details," he said... (not enough details may lead to quantity maxim flouting)

(Source::www.guardian.co.uk/world/2011/may/04/osama-bin-laden-photos raid $+\% 22$ there $+i s+n o+$ further + details + bin + laden + death\% $22 \& c d=3 \& h l=f a \& c t=c \ln k$ )

3) Official sources said that both sides will 'explore ways' to reduce tension and to revive the peace efforts in Afghanistan. (observing the quality maxim)

(Source: http://www.irna.ir/ENNewsShow.aspx?NID=30609832\&SRCH=1)

4) ...The officials said the DNA testing alone offered a "99.9 percent" certainty that bin Laden was shot dead in a daring U.S. military operation. Detailed photo analysis by the CIA, confirmation by other people at the raid site and matching physical features like bin Laden's height all helped confirmed the identification... (various tactics to strengthen the observation of the quality maxim).

(Source: http://www.dispatch.com/content/stories/national_world/2011/05/02/dna-identifies-bin-laden.html)

These are only a few examples of the application of Grice maxims in routine news production process and further researches should be done to explore its different aspects such as linguistic role and structure of maxims in various (meta) lingual levels, their influence on transferring meaning to the audience,(social and professional) causes and effects of maxim flouting, and so on so forth. Quantitative researches on newspaper archives and doing systematic and ethnographic interviews with journalists and news editors can also shed further light on other sides of the mechanisms of applying these maxims by journalists and the way the maxims are checked by editors in so called gatekeeping stage.

\section{CONCLUSION}

In this article, we went through the news selection process, mainly focused on the theoretical concept of "news value" as the most widely known aspect of selection process and also discussed the post-Galtung achievements in this field in brief. The lists of news values posited by various media and social science scholars seem endless and almost all researchers who have studied this concept may suggest a new set of news values based on the data and methodology chosen.

In this paper we hypothesized that the four maxims of Grice can be considered as a set of (universal?) news values which potentially can summarize many news criteria of different lists. However, we are aware of this fact that news selection is a multi level process in which many cultural, social, professional and cognitive factors are playing role and suggestion of Grice maxims as linguistic criteria of news selection is limited only to composition level (not publication or post publication stage.)

Regarding Grice maxims as linguistic set of news values not only shows the potentiality of expanding the Maxims to non conversational contexts but also makes a set of brief and rather concrete criteria available for the journalists and editors to evaluate the outcome of their production process. 
In this article only few instances of the application of maxims in the news were exemplified and more complementary researches and case studies are necessary to explore various aspects of this suggestion (especially the maxim flouting) profoundly.

\section{REFERENCES}

[1] Aghagolzade, F. \& R. Kheirabadi (2008). A linguistic study of news values in Iranian press. The international journal of humanities of the Islamic republic of Iran 15(1),1-7.

[2] Albert Braun, J. (2009). Rehashing the Gate: News Values, Non-News Spaces, and the Future of Gatekeeping. M.S Thesis, Cornell University.

[3] Allern, S. (2002). Journalistic and commercial news values: News organizations as patrons of an institution and market actors. Nordcom Review, 23(1-2), 137-152.]

[4] Bell, A. (1991). The language of news media. Oxford: Blackwell.

[5] Brighton, P. and D. Foy, (2007). News values. London: Sage Publications.

[6] Chomsky, N. \& E. S. (1998). Manufacturing consent. New York: Pantheon Books.

[7] Cohen, S. \& J. Young (eds.) (1981). The Manufacture of News: Deviance, Social Problems and the Mass Media (2nd edn.). London: Constable. pp. 69-90.

[8] Cook,G. (1992). The discourse of advertising. London: Routledge.

[9] Fairclough, N. (2003). Analysing discourse. London: Routledge.

[10] Fairclough, N. (1992). Discourse and social change. Cambridge.

[11] Fairclough, N.(1995). Media discourse. London: Arnold.

[12] Fowler, R. (1991). Language in the news. London: Routledge.

[13] Galtung, J. \& M. H. Ruge (1965). The structure of foreign news: The presentation of the Congo, Cuba and Cyprus crises in four Norwegian newspapers. Journal of Peace Research, 2 (1), 64-90.

[14] Gans, H. J. (1979). Deciding what's news: A study of CBS Evening News, NBC Nightly News, Newsweek and Time. New York: Pantheon Books.

[15] Golding, P. \& P. Elliott, (1979). Making the news. In H. Tumber (ed.), News: A reader, New York: Oxford University Press,112-120.

[16] Gregory, J. \& S.Miller, (1998). Making news out of science. In Science in public Communication, culture, and credibility, New York: Plenum, 108-114.

[17] Grice, H. P. (1975). Logic and conversation. In Cole, P. \& J. L. Morgan (eds.) Syntax and semantics: Speech acts 3. New York: Academic Press. 58-85.

[18] Grice, H. P. (1989). Studies in the way of words. Cambridge: Harvard University Press.

[19] Hall, S. (1973). The determinations of news photographs. In S. Cohen \& J. Young (Eds.), The manufacture of news: Social problems, deviance and the mass media, Communication and society. Beverly Hills: Sage Publications, 176-190.

[20] Harcup, T. \& D.O'Neill (2001). What is news? Galtung and Ruge revisited. Journalism Studies, 2(2), 261-280.

[21] Harrison, J. (2006) News. Abingdon: Routledge.

[22] Herbert, J. (2000). The purpose and meaning of news. In Journalism in the digital age: Theory and practice for broadcast, print and on-line media, Boston: Focal Press, 59-73.

[23] Hetherington, A. (1985). What's news? Who makes the news? In News, newspapers and television, London: Macmillan Press, 1-21.

[24] Hoey, M. (2001). Textual interaction. London: Routledge.

[25] Lindblom, K. (2006). Cooperative Principle in J. L. Mey (ed.) (2009) Concise Encyclopedia of Pragmatics Oxford: Elsevier Ltd, 151-158.

[26] McQuail, D. (2000). McQuail's mass communication theory (4th ed.). Thousand Oaks: Sage Publications.

[27] McQuail, D. (1994). Mass communication theory. London: Sage.

[28] MacShane, D. (1979). Using the Media. London: Pluto Press.

[29] O'Neill, D. and T. Harcup, (2009). News values and selectivity. In T. Wahl-Jorgensen, K. Hanitzsch, (2009). The handbook of journalism studies, New York: Routledge.

[30] O'Sullivan, T., J. Hartle, D. Saunders, \& J. Fiske, (1983). News values. In Key concepts in communication, Studies in communication. New York: Methuen, 153-155.

[31] Palmer, J. (1998). News production, news values. In A. Briggs \& P. Cobley (Eds.), The media: An introduction Harlow: Longman, 117-132.

[32] Ruehlmann, W. (1979). Ideas. In Stalking the feature story. New York: Vintage Books, 94-114.

[33] Ryan, C. (1991). What's newsworthy? In Prime time activism: Media strategies for grassroots organizing. Boston: South End Press,31-52.

[34] Sande, O. (1971). The perception of foreign news. Journal of Peace Research, 8(3/4),221-237.

[35] Tunstall, J. (Ed.). (1970). Media sociology. London: Constable.

[36] van Dijk, T. (1988). News as Discourse. Hillsdale, NJ: Erlbaum.

[37] Warner, M. (1970). Decision-making in network television news. In Media sociology: A reader, Chicago: University of Illinois Press, 158-167.

[38] Yule, G. (2000). Pragmatics. London: Oxford University Press.

[39] Zelizer, B. (2004). Taking journalism seriously: News and the academy. London: Sage. 
Reza Kheirabadi was born in Tehran, Islamic Republic of Iran in 1979. He is a PhD candidate of General Linguistics in Tarbiat Modares University (Tehran, Iran) and received his M.A. from the same university in 2006.He is now passing a 6 months scholarship in Gent, Belgium with News Text and Talk (NT\&T) Research Group.

$\mathrm{He}$ is currently working for Organization for Educational Research and Planning (OERP) which is the official body to prepare textbook materials and curriculum planning in Islamic Republic of Iran. He also has the experience of working for leading Iranian newspapers and news agencies as journalists and translator. His main research interests are News production process, Language of News, Critical Discourse Analysis of news and ethnographic study of journalistic activities in Iran. His MA thesis was also about linguistic study of news values in press of Iran.

Mr. Kheirabadi is a research assistant of NT\&T and a member of Public Relations Expert Association of Islamic Republic of Iran.

Ferdows Aghagolzadeh is associate professor of General linguistics in Tarbiat Modares University, Tehran. Islamic Republic of Iran. He received his $\mathrm{PhD}$ in 2001 from Tarbiat Modares University. He has been the advisor of many master and PhD researches.

His main field of interests are (Critical) Discourse Analysis, Sociology, Dialectology, Persian Language Teaching and related subjects. He has authored many articles and books, among books Critical Discourse Analysis (Tehran, Iran: Elmi Farhangi Publications,2005) and Analysis of Radio Discourses Based on Linguistic Theories and Strategies (Tehran, Iran: Tarhe Now, 2009) to the subject of this article. 